\title{
Development and testing of a model of unified funds of assessment materials for reviewing subject and methodological competencies of biology teachers
}

\author{
Elena Arbuzova ${ }^{1,2}$, Vitalina Loshenko ${ }^{3}$, Roman Oparin $^{3}$, Andrey Sakharov ${ }^{3}$, and Sergey \\ Sumatokhin ${ }^{4}$ \\ ${ }^{1}$ Omsk Academy of the Humanities, 4-ya Chelyuskintsev St., 2a, 644105 Omsk, Russia \\ ${ }^{2}$ Moscow State Regional University, st. Vera Voloshin, 24, 141014 Mytishchi, Moscow region \\ ${ }^{3}$ Novosibirsk State Pedagogical University, Vilyuyskaya Street, 28, 630126 Novosibirsk, Russia \\ ${ }^{4}$ Moscow City Pedagogical University, 2-j Selskohozyajstvennyj proezd, 4, 129226 Moscow, Russia
}

\begin{abstract}
The article is devoted to the problem of development and testing of diagnostic tools for monitoring the ability of teachers of general educational institutions to solve professional and pedagogical problems. The model of unified fund of assessment materials (UFAM) is aimed at reviewing subject and methodological competencies of biology teachers. It provides examples of tasks in biology with the methods of teaching it. A brief analysis of the model review results has been provided.
\end{abstract}

\section{Introduction}

The article is devoted to the current problem of development and testing of diagnostic tools for monitoring of the ability of teachers of general educational institutions to solve professional and pedagogical problems. The model of unified funds of assessment materials (UFAM) is aimed at reviewing subject and methodological competencies of Biology teachers. It provides some examples of tasks in Biology and the methods of teaching it. There is a brief analysis of the model testing results performed in 69 regions of the Russian Federation. It has identified the principal difficulties of teachers in their subject and methodological training. It proposes topics for professional development courses for Biology teachers.

Nowadays, one of the main goals of a modern school is to improve the quality of education [1-2]. The decree "On national goals and strategic objectives of development of the Russian Federation for the period before 2024" states that by 2024 Russia should enter the top ten of countries by the quality of general education [3]. This requires introduction of new teaching methods and technologies into education, and creation of an effective system for finding and supporting gifted students. The fundamental idea in the system of general education is activity-based approach [4-5]. According to Professor S.V. Sumatokhin, contextualization of the content and learning activities should become the leading direction in the development of school biological education $[4,6]$.

Numerous studies have shown that the quality of education system depends on the 
competence of teachers engaged. None of the factors correlates as strongly with student outcomes as the quality of teaching staff [7].

Ministry of Enlightenment of the Russian Federation is currently developing a unified model to be used to promote the professional development of teachers. The model has five blocks: subject, methodological, psychological and pedagogical, and educational. Teacher internships will become mandatory.

In 2019, the Ministry of Enlightenment launched a project to develop and test the model of the Unified Fund of Assessment Materials (UAMF) to assess the level of subject and methodological training of teachers [8]. Our team of authors developed and tested a subproject of UAMF for Biology teachers.

The sub-project purpose is to develop a model for assessment of subject and methodological competencies of Biology teachers.

Objectives

- to develop tools (EFOM) to assess competence Biology teachers in solving professional tasks related to the content of school Biology curriculum, teaching methods, psychological and pedagogical foundations of modern education;

- to identify the relationship between the formation of competencies of a teacher and the data characterizing the context of professional activity;

- to identify shortcomings (difficulties) of Biology teachers, arising in the process of solving professional tasks;

- to determine prospects for professional development of Biology teachers, based on the identified shortcomings;

- to develop recommendations for certification of Biology teachers.

\section{Materials and methods}

Complex of research methods used to implement the objectives:

- theoretical: analysis and synthesis, analogy, modeling, generalization and systematization, analysis of works in the area of professional development of Biology teachers, professional standards of teachers, constructive modeling;

- empirical: study and generalization of pedagogical experience, analysis of results of professional activity of Biology teachers; design of educational and methodological support for assessment of subject and methodological competencies; self-analysis by Biology teachers of subject and methodological training, analysis of pedagogical documentation; surveys and diagnostic methods, testing; evaluation and self-assessment, expert evaluation.

methods of processing the experimental data: mathematical, statistical.

More than 1,000 Biology teachers participated in the testing whereas 120 experts have been involved. Demo version gives an idea of the structure of the diagnostic work, the task numbers, the form of the tasks, the levels of difficulty of the tasks and criteria for assessing their performance.

\section{Results and discussion}

A model of diagnostic work to assess the subject and methodological competencies of Biology teachers has been developed [9]. More than 1,000 Biology teachers participated in the testing whereas 120 experts have been involved [10]. Demo version gives an idea of the structure of the diagnostic work, task numbers, tasks forms, levels of difficulty of the tasks and criteria for assessing their performance. It consists of three parts:

I. twelve tasks to assess the subject competencies of a teacher, presented in test form; 
II. tasks in PISA format;

III. tasks to assess the methodological competencies of a teacher, presented in the form of practice-oriented case tasks.

Examples of tasks in Part I

1. Closed-type tasks with one correct answer.

The cell energy supply system is structurally represented by mitochondria and plastids. When cellular oxygen consumption decreases, ATP synthesis is depressed. Choose the correct explanation for this statement:

1) lack of oxygen in the cell blocks processes of anaerobic glycolysis;

2) lack of oxygen in the cell reduces the level of oxidation of substrates in Krebs cycle and citric acid;

3) lack of oxygen in the cell decreases phosphorylation processes in mitochondrial matrix;

4) lack of oxygen in the cell reduces the processes of oxidative phosphorylation in mitochondria.

Answer: 4

2. Closed-type multiple-choice tasks.

Choose three structures belonging to the pulmonary circulation:

1) superior vena cava;

2) carotid artery;

3) pulmonary artery;

4) left atrium;

5) right ventricle;

6) left ventricle.

Answer: 345

3. Open-type tasks to add a term.

Examine the suggested diagram. Write down the missing term in the diagram marked with a question mark.

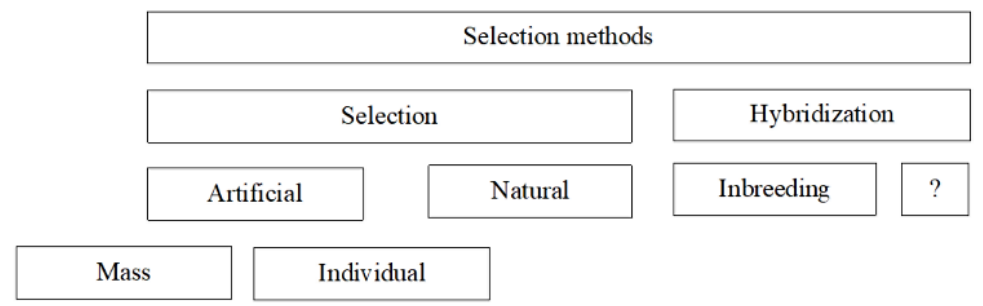

Answer: Outbreeding

4. Closed-type matching tasks.

Connect the organism with its characteristic traits. For each item in the left column, choose two corresponding items from the right column.

\begin{tabular}{|l|l|}
\hline ORGANISM & CHARACTERISTIC \\
\hline \multirow{3}{*}{$1)$} & $\begin{array}{l}\text { A) parthenogenesis } \\
\text { 2) phototaxis }\end{array}$ \\
\hline & $\begin{array}{l}\text { C) heterotrophic nutrition } \\
\text { D) pseudopodia formation } \\
\text { E) conjugation process }\end{array}$ \\
\hline $\begin{array}{l}\text { F) predominance of haploid generation in the life } \\
\text { cycle }\end{array}$ \\
\hline
\end{tabular}

An example of a PISA-type task from Part II 
The most important problem of genetics in the middle of the $21^{\text {st }}$ century is genetic code sequencing, determining the connection between the sequence of nucleotides in nucleic acids and the strict sequence of amino acids in a protein molecule. The unit of genetic code is a codon, or triplet, a section of DNA consisting of a combination of three nucleotides and one encoding amino acid residue of a protein polypeptide chain. Triplet structure is basic property of genetic code. Genetic code does not overlap, it is universal and this is its main property. Translation of information from the language of nucleic acids to the language of amino acids is carried out with the help of transport RNAs. "Assembly" of a protein molecule according to the information on its structure recorded in the informational RNA is called translation. During this process, information on the specific structure of the future protein, recorded as a sequence of nucleotides in an informational RNA molecule, is translated from the nucleotide code into a specific sequence of amino acids of synthesized proteins. The flow of genetic information during protein biosynthesis goes in the direction of DNA $\rightarrow R N A \longrightarrow$ protein. Such a pattern is called the central dogma of molecular biology. It is this process that represents the key mystery of life, which has not yet been fully solved.

1. All but two of the following features can be used to describe the process of protein biosynthesis in a cell. Identify two features that are out of the list and write down their numbers:

1) the process occurs in the presence of enzymes;

2) RNA molecules play the central role in the process;

3) the process is accompanied by the synthesis of ATP;

4) amino acids serve as monomers for the formation of molecules;

5) protein molecules are assembled in the smooth endoplasmic reticulum.

2. Changing the sequence of DNA nucleotides does not always affect protein structure and its functions. Give justification for this statement.

3. Identify the correct reaction sequence that take place during protein biosynthesis. Write down the corresponding sequence of numbers:

1) DNA molecule detorsion;

2) junction of informational RNA to ribosome;

3) attachment of certain amino acid to the transport RNA;

4) release of informational RNA into cytoplasm;

5) gradual build-up of polypeptide chain;

6) synthesis of informational RNA on one of the DNA strands.

The $6^{\text {th }}$ grade student participated in the All-Russian Biology Testing. Familiarize yourself with his work, the task, and evaluation criteria. Check the student's work according to the suggested criteria and give a final score. Justify the score.

\section{8}

Water and the minerals dissolved in it are known to move up the plant. Nikolai decided to check this fact by conducting the following experiment. He placed the clipped snowdrop flowers in two vessels with clean and tinted water (Fig. A). A few days later he saw the following changes (Fig. B). 

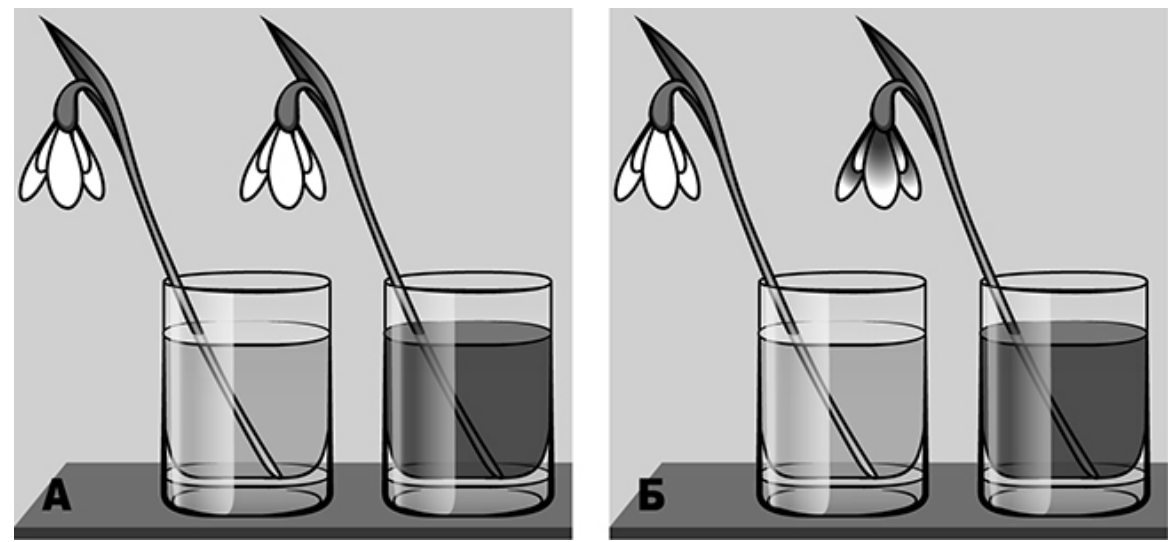

8.1 .

What change happened to the petals of the snowdrop flower when it was placed in a vessel with tinted water?

Answer: the petals gained color

8.2. What does the result of the experiment prove?

Answer: the stem conducts substances dissolved in water, in this case, it is ink, and in the nature, it is mineral salts dissolved in water

83. Which plant tissue gave you the result of your experiment? Justify your answer.

Answer: conductive tissue, sieve tubes

Based on the results of the student's knowledge and skills in Biology, suggest options for further work with the student.

\begin{tabular}{|l|l|l|}
\hline Evaluation criteria & Points \\
\hline K1 & Stating the result of the biological experiment & 1 \\
\hline & $\begin{array}{l}\text { The answer to the question has to disclose the influence of environmental conditions } \\
\text { on the life cycle of a biological object. } \\
\text { K1 } 1 \text { point (the given result of biological experiment is correct. The answer to the } \\
\text { question reveals the effect of environmental conditions on a biological object, for } \\
\text { example, the color of flower petals has changed or petals gained color) }\end{array}$ & \\
\hline & Correct answer & 1 \\
\hline & $\begin{array}{l}\text { Incorrect answer } \\
\text { K2 }\end{array}$ & 0 \\
\hline & $\begin{array}{l}\text { Thalysis of the result of the biological experiment } \\
\text { by the experiment }\end{array}$ & 1 \\
\hline & $\begin{array}{l}\text { Correct answer } \\
\text { Incorrect answer }\end{array}$ & 1 \\
\hline K3 & $\begin{array}{l}\text { Analysis of processes in a living organism, based on the results of biological } \\
\text { experiment }\end{array}$ & 2 \\
\hline & $\begin{array}{l}\text { The answer to the question has to be justified, revealing the biological phenomena, } \\
\text { processes, patterns on the example of the organism. Correct answer has to contain the } \\
\text { following elements: answer to the question, justification }\end{array}$ \\
\hline & The answer is correct, the justification is given & 2 \\
\hline & The answer to the question is correct, the justification is not given / given incorrectly & 1 \\
\hline & $\begin{array}{l}\text { The answer to the question is missing / given incorrectly regardless of the presence of } \\
\text { justification or the answer is incorrect }\end{array}$ & 0 \\
\hline
\end{tabular}


Crude answer, evaluation criteria, and comments for the expert

\begin{tabular}{|c|c|c|}
\hline & nd its description \\
\hline \multicolumn{2}{|c|}{$\begin{array}{l}\text { The answer has to include certain elements: score for the task ( } 3 \text { points) and justification: } \\
\text { - K1 - } 1 \text { point (the given result of biological experiment is correct. The answer to the question reveals } \\
\text { the effect of environmental conditions on a biological object, for example, the color of flower petals has } \\
\text { changed or petals gained color) } \\
\text { - K } 2-1 \text { point (the answer to the question is correct. Standard answer: There are channels (cavities) } \\
\text { between the stem and petals of the snowdrop through which water moves with dissolved substances or } \\
\text { water moves up the plant with dissolved substances; } \\
\text { - K3 - } 1 \text { point (the answer is half right. The name of the tissue is given, but the conductive elements are } \\
\text { named incorrectly. Answer example: conductive tissue is formed by vessels - long tubes. Water and the } \\
\text { minerals dissolved in it move up the plant. } \\
\text { Options for further work with the student: } \\
\text { - the student who made the mistake needs to get explained the concept of types of plant tissues, in } \\
\text { particular conductive tissues, as well as their structure and functions; } \\
\text { - if the student failed to justify the answer, it is desirable to explain the structure and functions of } \\
\text { conductive tissue using the tables, it is possible to use digital educational resource on this topic; } \\
\text { - if the task based on the previously studied material is not completed at all, it is necessary to } \\
\text { recommend to the student to work with the textbook; } \\
\text { - it is advisable to suggest that the student does this experiment at home with a houseplant, such as a } \\
\text { sprig of impatiens, or suggest that the student puts poplar sprigs in the tinted water. To observe, analyze } \\
\text { the results and to draw a conclusion about the movement of water with dissolved minerals along the wood } \\
\text { vessels by the upward current. Suggest drawing a longitudinal and transverse section of dyed poplar sprig } \\
\text { in a notebook. }\end{array}$} & \\
\hline & & \\
\hline & & \\
\hline K3 & & \\
\hline & & \\
\hline
\end{tabular}

The results of reviewing the subject and methodological competencies of teachers on Part I of the diagnostic work allowed us to identify which issues of school Biology cause difficulties for Biology teachers. Table 1 shows the potential for pedagogical growth of teachers in Biology, as well as recommended professional development courses.

Table 1. Analysis of the difficulties experienced by teachers in Part I of diagnostic work on Biology and recommended professional development programs

\begin{tabular}{|c|c|c|}
\hline \begin{tabular}{|l|} 
Task \\
number
\end{tabular} & $\begin{array}{l}\text { Potential for pedagogical growth based } \\
\text { on the results of Part I }\end{array}$ & Recommended professional development programs \\
\hline 1 & $\begin{array}{l}\text { Lack of modern understanding of methods } \\
\text { of biological scientific research }\end{array}$ & $\begin{array}{l}\text { Modern concepts of Biology as a science. Subject training } \\
\text { for teachers to improve quality of biological education for } \\
\text { school students }\end{array}$ \\
\hline 2 & Lack of knowledge of nucleotide structure & $\begin{array}{l}\text { Modern concepts of the cell as a biological system. Subject } \\
\text { training for teachers to improve quality of biological } \\
\text { education for school students }\end{array}$ \\
\hline 3 & $\begin{array}{l}\text { Failures in matching between an organism } \\
\text { and its characteristic traits }\end{array}$ & $\begin{array}{l}\text { Modern view on the study of organisms as biological } \\
\text { systems. Formation of scientific competence of teachers in } \\
\text { the context of transition to a new quality of biological } \\
\text { education in the Russian Federation }\end{array}$ \\
\hline 7 & $\begin{array}{l}\text { Lack of understanding of ecosystem } \\
\text { components and environmental factors }\end{array}$ & $\begin{array}{l}\text { Modern theoretical ideas on ecology as a science. } \\
\text { Development of scientific competence of Russian school } \\
\text { students through improved subject-specific training of } \\
\text { Biology teachers }\end{array}$ \\
\hline 8 & $\begin{array}{l}\text { Unfamiliarity with the features that are } \\
\text { characteristic for plants as a kingdom of } \\
\text { wildlife }\end{array}$ & $\begin{array}{l}\text { Selected chapters in systematics and diversity of the - } \\
\text { forganic world. Subject training for Biology teachers to } \\
\text { improve quality of biological education for school students }\end{array}$ \\
\hline 9 & $\begin{array}{l}\text { Difficulties in matching functions and } \\
\text { parts of the human brain; hormones and } \\
\text { the glands that secrete them }\end{array}$ & $\begin{array}{l}\text { The human body and its health as an object of study in } \\
\text { science and academic subject. Subject training for teachers } \\
\text { to improve quality of biological education for school } \\
\text { students }\end{array}$ \\
\hline
\end{tabular}


Table 1. Continued

\begin{tabular}{|c|c|c|}
\hline 10 & $\begin{array}{l}\text { Unfamiliarity with traits uncharacteristic } \\
\text { of biological progress; factors that do not } \\
\text { characterize anthropogenesis; statements } \\
\text { that do not belong to the synthetic theory } \\
\text { of evolution; statements confirming that } \\
\text { the population is the "unit of evolution" }\end{array}$ & Modern ideas on the evolution of $\mathrm{w}$ \\
\hline 11 & $\begin{array}{l}\text { Unfamiliarity with cells that are formed by } \\
\text { meiosis and mitosis }\end{array}$ & $\begin{array}{l}\text { Modern concepts of the cell as a biological system. Subject } \\
\text { training for teachers to improve quality of biological } \\
\text { education for school students }\end{array}$ \\
\hline 12 & $\begin{array}{l}\text { Difficulties in identifying inherited } \\
\text { variability; identifying stages of post- } \\
\text { embryonic development; identifying type } \\
\text { of hybridization }\end{array}$ & $\begin{array}{l}\text { Selected problems of genetics and selection. } \\
\text { Modern view on the study of organisms as biological } \\
\text { systems }\end{array}$ \\
\hline 14 & $\begin{array}{l}\text { Unfamiliarity with peculiarities of sexual } \\
\text { reproduction }\end{array}$ & $\begin{array}{l}\text { Modern view on the study of organisms as biological } \\
\text { systems }\end{array}$ \\
\hline 15 & $\begin{array}{l}\text { Difficulty in matching a living organism } \\
\text { with the ecological group to which it } \\
\text { belongs }\end{array}$ & $\begin{array}{l}\text { Modern theoretical ideas on ecology as a science. Subject } \\
\text { training for Biology teachers to improve quality of } \\
\text { biological education for school students }\end{array}$ \\
\hline 16 & $\begin{array}{l}\text { Difficulties in filling in the blanks with } \\
\text { terms from the suggested list of questions } \\
\text { about organ systems and double } \\
\text { fertilization in the angiosperms }\end{array}$ & $\begin{array}{l}\text { Selected chapters in systematics and diversity of the } \\
\text { organic world. Subject training for Biology teachers to } \\
\text { improve quality of biological education for school students }\end{array}$ \\
\hline 17 & $\begin{array}{l}\text { Unfamiliarity with the features typical for } \\
\text { some functional systems of the cell }\end{array}$ & $\begin{array}{l}\text { Modern concepts of the cell as a biological system. Subject } \\
\text { training for teachers to improve quality of biological } \\
\text { education for school students }\end{array}$ \\
\hline 19 & $\begin{array}{l}\text { Difficulties in matching a plant and the } \\
\text { features of its structure; a fungus and the } \\
\text { taxon to which it belongs according to the } \\
\text { scientific classification }\end{array}$ & $\begin{array}{l}\text { Modern view on the study of organisms as biological } \\
\text { systems }\end{array}$ \\
\hline 20 & $\begin{array}{l}\text { Difficulties in completing a high-level } \\
\text { difficulty task within the framework of } \\
\text { modern understanding of patterns of cell } \\
\text { system functioning }\end{array}$ & $\begin{array}{l}\text { Modern concepts of the cell as a biological system. } \\
\text { Subject training for Biology teachers to improve quality of } \\
\text { biological education for school students }\end{array}$ \\
\hline
\end{tabular}

The tasks in Part II of the diagnostic work are drawn up in the PISA format. Each task has two basic level questions ( 1 point) and one advanced level question ( 2 points). Table 2 shows the difficulties associated with their completion.

Table 2. Analysis of the difficulties experienced by teachers in Part II of the diagnostic work on Biology and topics of recommended professional development courses

\begin{tabular}{|c|c|c|}
\hline \begin{tabular}{|l|} 
Task \\
number
\end{tabular} & $\begin{array}{l}\text { Potential for pedagogical growth based on the results of } \\
\text { Part II }\end{array}$ & $\begin{array}{l}\text { Recommended } \\
\text { development programs }\end{array}$ \\
\hline $21.2,21.3$ & $\begin{array}{l}\text { No clear picture of the types of plant nutrition (errors in the } \\
\text { distinguishing between heterotrophic and autotrophic } \\
\text { organisms on the example of carnivorous plants). } \\
\text { Ecological groups of plants are identified incorrectly. } \\
\text { Difficulty in explaining how plants transitioned to a } \\
\text { heterotrophic type of nutrition (using carnivorous plants as } \\
\text { an example) }\end{array}$ & $\begin{array}{l}\text { Modern ideas about the structure and } \\
\text { functions of ecological systems. } \\
\text { Ecological groups of plants by type of } \\
\text { nutrition }\end{array}$ \\
\hline $\begin{array}{l}22.2 \\
22.3\end{array}$ & $\begin{array}{l}\text { The main systematic (taxonomic) categories: species, genus, } \\
\text { family, order, class, type (division), kingdom are identified } \\
\text { incorrectly. No clear picture of protozoa, their } \\
\text { morphological and physiological features }\end{array}$ & $\begin{array}{l}\text { Systematics and evolution of living } \\
\text { organisms. Current understanding of } \\
\text { structure and physiology of protozoa }\end{array}$ \\
\hline $\begin{array}{l}21.1 \\
21.2 \\
21.3\end{array}$ & $\begin{array}{l}\text { No clear picture of modern cell theory (differences between } \\
\text { prokaryotic and eukaryotic cells). } \\
\text { Unable to apply knowledge of cellular theory to explain the } \\
\text { unity of the organic world, to prove the kinship of wildlife. } \\
\text { Incorrect identification of concepts of genetic information in } \\
\text { the cell, genetic code and its properties; matrix nature of } \\
\text { biosynthesis reactions }\end{array}$ & $\begin{array}{l}\text { Fundamentals of cytology and genetics. } \\
\text { Cytology and genetics in the school } \\
\text { course of Biology }\end{array}$ \\
\hline
\end{tabular}


Table 2. Continued

\begin{tabular}{|l|l|l|}
21.1, & $\begin{array}{l}\text { Unable to apply knowledge of the laws of evolution to } \\
\text { explain adaptation of organisms to their environment and } \\
\text { diversity of species }\end{array}$ & $\begin{array}{l}\text { and evolution of living } \\
\text { organisms. Modern ideas about the } \\
\text { theory of evolution, structure, and } \\
\text { functions of ecological systems }\end{array}$ \\
\hline
\end{tabular}

As a result of assessment of methodological competencies of Biology teachers, we obtained the following results.

Task 23 allowed us to assess actions of a teacher in planning lessons in accordance with the content of the basic general education curriculum and taking into account individual characteristics of students, including students with special educational needs. For the first criterion of this task, $38.4 \%$ of participants received 2 points, for the second $-22.2 \%$. More than one-third of teachers had difficulty completing this task.

Task 24 is aimed at checking the performance in classes in accordance with the curricula and working programs of academic subjects, courses using modern teaching methods. The number of participants who failed ranged from 42 to $87.9 \%$. Teachers gave the worst answers to the tasks in form 7. For example: "During the lesson, a teacher solves the problem of formation of general biological concepts of supraorganismal level, such as "ecosystem" and "biogeocenosis". What kind of visual aids from the following is appropriate to use during the deductive course of material explanation? Explain your answer. What other teaching tools would you use to form this ecological concept?"

Most participants chose method 2 (biocenosis), as well as 1 and 3; only $6.7 \%$ of them gave the correct answer $-1-$ the structure of biogeocenosis according to V.N. Sukachev. The majority of teachers, $81.8 \%$, were not able to complete task 24 in form 7 . The assignment included a lesson plan based on which teachers had to choose the right answer and justify it.

Task 25 is aimed at assessing the ability to use information and communication technologies to form a digital learning environment in the classroom. The percentage of those who completed it was 48-64\%. An example of a task: "One of the tasks of a modern high school biology course is to teach students to use media resources to acquire knowledge, to critically analyze and evaluate the completeness and reliability of information in the media, including the Internet, using a variety of media tools. We offered to answer the question: what kind of homework on the proposed topic will help the teacher more effectively solve the problem of teaching students to critically analyze the resources of biology-related content of the information environment of modern society? In general, the participants did well in this task. $31.6 \%$ to $35.4 \%$ of teachers answered incorrectly.

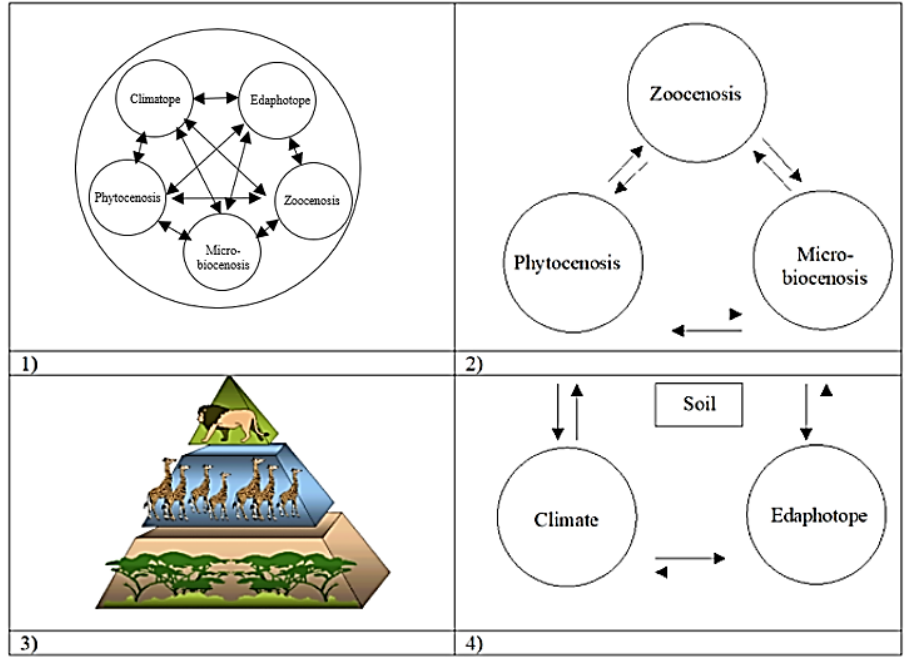


Task 26 is associated with an objective evaluation of the educational outcomes of students in accordance with the requirements of the FSES (Federal State Education Standards) of the corresponding level of general education to adjust and individualize the forms and methods of teaching. The task structure was as follows: announcing the topic of the lesson and offering a set of tasks to the students. They were required to answer a question related to the analysis of the content of the geochronological table. More than $40 \%$ of participants completed this task, but the percentage of incorrect answers for individual options is ranging widely - from $38.9 \%$ to $73.6 \%$. The difficulty is related to the ability to analyze evolutionary concepts, provide a level differentiation assessment of knowledge of students.

Task 27 is aimed at assessment of the work of teacher on ensuring full engagement of school students (including those with special educational needs) in learning activities. Its wording in all forms was standard: description of situation with appearance of a student with certain educational needs in the class; presentation of a fragment of decision of local Psychological, Medical and Pedagogical Commission (PMPC). The teacher was asked to name and describe the actions necessary to prepare for work with such a student. The overall results for all forms are satisfactory. For the first criterion (understanding that the basis for creation of special educational conditions for a student is the PMPC decision, orientation to use the conclusions and recommendations of PMPC in practice) the percentage of success was $69.6 \%$, for the second (understanding that work with this student should be based on an adapted educational program, developed in the view of the General Adapted Educational Program for the group of students with disabilities) $-68.4 \%$. For the third criterion (competent use of pedagogical terminology) $-74.8 \%$. The participants who had forms 7 and 8 failed task 27. They were offered this task:

Commission decision

According to the results of a complex psychological, medical and pedagogical examination, partial underdevelopment of the higher mental functions of a mixed type was established. Social and educational neglect. Speech development is within conditional age norm.

A student with disabilities needs special educational conditions.

Task 28 involved an assessment of actions of a teacher aimed at ensuring full participation of students (including those with special educational needs) in learning activities. Participants had to demonstrate actions aimed at pedagogical assistance to the student in their choice of future work and compliance with the rules of professional ethics in communicating with them and their parents (legal representatives). The first criterion is met by almost $70 \%$ of teachers, and the second criterion by about $80 \%$. These results demonstrate the willingness of teachers to provide students with necessary pedagogical assistance. However, $52.3 \%$ of the participants did not show a response or they did not fully meet the second criterion. For example, the requirements of normative documents (FSES, specification, codifier and demo version of the Basic State Examination/Uniform State Exam in Biology, local acts of the school, etc.) were not specified. The best results for this task were obtained in forms 1,2 , and 4 .

Task 29 is aimed at assessment of ability of a teacher to evaluate outcomes of the students in the subject. Participants were offered texts of tasks for school students, fragments of their work and criteria for their evaluation. They were asked to evaluate the works of students according to the criteria and justify their actions. 55.7\% of teachers correctly evaluated works of students; $61.7 \%$ justified the scores based on the suggested criteria for task evaluation; $49.8 \%$ suggested the option of further work with students, based on the identified errors. Most participants showed satisfactory level of performance on this task. However, we noted a high percentage of incorrect answers for the first criterion evaluation of work of the students (91.6\%). A rather high percentage of incorrect answers 
for the second (73.8\%) and third (86.0\%) criteria. Difficulties with the evaluation of the work of students might be associated with the fact that we had to consider a set of criteria for two tasks of individual work at once. Table 3 shows an analysis of professional shortcomings and proposed professional development courses to address them.

Table 3. Analysis of the difficulties experienced by teachers in Part III of diagnostic work on Biology and recommended professional development programs

\begin{tabular}{|c|c|c|}
\hline \begin{tabular}{|l|} 
Task \\
number
\end{tabular} & $\begin{array}{l}\text { Potential for pedagogical professional growth based } \\
\text { on the results of Part III }\end{array}$ & $\begin{array}{l}\text { Recommended professional development } \\
\text { programs }\end{array}$ \\
\hline 23 & $\begin{array}{l}\text { When formulating lesson goals and determining the } \\
\text { order of actions to achieve them, pay attention to the } \\
\text { requirements of the FSES for learning outcomes }\end{array}$ & $\begin{array}{l}\text { Assessment of learning outcomes in Biology } \\
\text { classes. FSES for general education and the } \\
\text { subject related methodological content of the } \\
\text { educational process in Biology. Development } \\
\text { of methodological competence of Biology } \\
\text { teachers in the context of improvement and } \\
\text { adoption of the new concept in the area of } \\
\text { Biology }\end{array}$ \\
\hline 24 & $\begin{array}{l}\text { When selecting didactic teaching aids, including visual } \\
\text { aids, attention should be paid to the practical training of } \\
\text { a Biology teacher }\end{array}$ & $\begin{array}{l}\text { Improvement of methodology of conducting a } \\
\text { Biology lesson in accordance with the } \\
\text { requirements of FSES of Basic General } \\
\text { Education and Secondary General Education }\end{array}$ \\
\hline 25 & $\begin{array}{l}\text { When using ICT for teaching Biology, it is necessary to } \\
\text { expand understanding of ICT tools, in particular, the } \\
\text { use of tools from different educational platforms }\end{array}$ & $\begin{array}{l}\text { ICT technologies in Biology classes. Media } \\
\text { education for modern Biology teacher }\end{array}$ \\
\hline 26 & $\begin{array}{l}\text { The greatest difficulty was the analysis of procedures } \\
\text { for conducting lessons in accordance with the curricula } \\
\text { and working programs of subjects and courses using } \\
\text { modern teaching methods and actions to assess learning } \\
\text { outcomes. It is necessary to pay attention to the fact } \\
\text { that tasks, focused on subject knowledge, should have } \\
\text { both meta-subject and personal character }\end{array}$ & $\begin{array}{l}\text { Improvement of methodology of conducting a } \\
\text { Biology lesson in accordance with the } \\
\text { requirements of FSES of Basic General } \\
\text { Education and Secondary General Education }\end{array}$ \\
\hline 27 & $\begin{array}{l}\text { Ensuring full participation of students (including those } \\
\text { with special educational needs) in learning activities. It } \\
\text { is necessary to pay attention to specific actions of the } \\
\text { teacher on organization of such work (to deepen } \\
\text { knowledge of the peculiarities of educational and } \\
\text { cognitive activity of students with various disabilities) }\end{array}$ & $\begin{array}{l}\text { Competence tasks as a means of assessing the } \\
\text { results in Biology } \\
\text { Technology (tools) of assessment and } \\
\text { monitoring (effectiveness) of learning } \\
\text { outcomes in Biology }\end{array}$ \\
\hline 28 & $\begin{array}{l}\text { Actions focused on pedagogical assistance to the } \\
\text { student in choosing their further assignments. } \\
\text { Compliance with the rules of professional ethics in } \\
\text { communicating with the student and their parents (legal } \\
\text { representatives) }\end{array}$ & $\begin{array}{l}\text { Methodological materials in the area of } \\
\text { Biology in basic school }\end{array}$ \\
\hline 29 & $\begin{array}{l}\text { Teachers have mastered the criterion-based approach to } \\
\text { evaluation of work of the students, but it is necessary to } \\
\text { pay attention to } \neg \text { element-by-element analysis of work } \\
\text { of the students and predicting their further assignments }\end{array}$ & $\begin{array}{l}\text { Competence tasks as a means of assessing the } \\
\text { results in the area of Biology }\end{array}$ \\
\hline
\end{tabular}

To summarize, we should note that most of the participants scored between $44-86(68 \%$ for the first part, $61 \%$ for the second part, and $18 \%$ for the third part, scoring the highest possible number of points). Over $69 \%$ of teachers successfully completed all Biology tasks, with $12 \%$ of participants scoring $86 \%$ or more.

The testing showed that such a project is relevant and in demand during the transition to a new level of quality in general education. The proposed model has been successfully tested in 69 regions of the Russian Federation. A total of 1,326 Biology teachers participated in the diagnostics. Identified shortcomings made it possible to propose topics for professional development courses in both methodological and subject areas. Results of monitoring in the course of UAMF model testing showed almost $100 \%$ correlation of competence of teachers with the results shown by students at Uniform State Exam in Biology in these regions of the country. 
Thus, a model for diagnostics of the competencies of Biology teachers has been created, which further was successfully tested, its results obtained and analyzed. The ways to improve the level of subject and methodological competence of teachers, and thus improve the quality of biological education in Russia, were outlined.
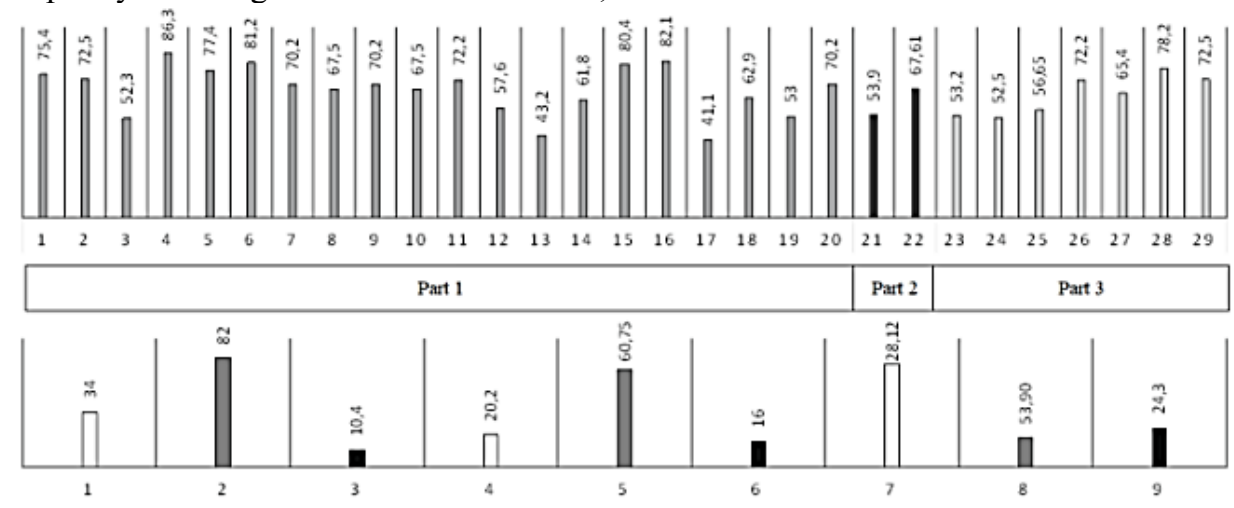

\begin{tabular}{|l|l|l|}
\hline Part 1 & Part 2 & Part 3 \\
\hline
\end{tabular}

scored the maximum number of points

successfully completed the task

failed the task

\section{Conclusions}

In conclusion of the study, it should be noted that in today's world with constantly changing conditions, it is important to maintain a high level of training of Biology teachers, because they are the main element in the construction of an effective system of education of the next generation regarding their interaction with the environment $[2,12]$. In this aspect, an important role is played by the scientific knowledge of students, which can only be achieved through the high level of subject competencies of Biology teachers. However, achieving this level is only possible with effective diagnostics. As teachers need to receive systematic, objective feedback on their level of competence and at the same time be motivated to transform themselves as professionals.

In this regard, the Russian Federation has developed a national system of the professional growth for teachers, which allows bringing the pedagogical system to a new benchmark - a professional standard [5]. Achieving this goal requires the new educational and pedagogical system to have new tools that allow not only objective diagnostics of professional, subject and other competencies of teachers, but also motivation of teachers with fair pay and creation of conditions for career development. These factors caused the Russian Federation to introduce a new tool that meets the above-mentioned requirements into its educational and pedagogical system, the UAMF [3].

Opportunities and ways of application were considered and analyzed on a group of teachers of different categories and a list of competence shortcomings and recommendations for their elimination were compiled based on this study.

We studied the theoretical foundations of implementation of unified federal assessment materials, including the concept of unified federal assessment materials and prerequisites for their implementation in educational system; found the types and areas of application of 
unified federal assessment materials, and also studied the world experience of using unified federal assessment materials in the context of their analogues and studied PIZA and TIMSS tasks in diagnostics of scientific knowledge [11]. Also, the first chapter analyzes the features of unified federal assessment materials in the context of modern biological and pedagogical education in Russia and considers the possibilities of using unified federal assessment materials. We reviewed the basic principles of development of assessment materials, using the example of two diagnostic works. Based on the results of my diagnostics, I compiled a list of necessary professional development courses, both for development of subject and methodological competencies of teachers, which will greatly facilitate and update teacher certification [12].

Thus, this project is relevant and in demand during the transition to a new level of quality education. The proposed model has been successfully tested in 69 regions of the Russian Federation. A total of 1,326 biology teachers participated in the testing. Identified shortcomings made it possible to propose topics for professional development courses in both methodological and subject areas. The results of testing the model of unified fund of assessment materials for Biology teachers showed almost $100 \%$ correlation of the results of diagnostics of subject and methodological competencies of teachers with the results obtained by students at Uniform State Exam in Biology in these regions. In the course of work on the project, a model for diagnostics of competencies of biology teachers was created. It has been successfully tested, its results obtained and analyzed. The model will be adjusted and improved in the future.

\section{References}

1. H. Cao, M.B. Amanbayeva, A.D. Maimatayeva, Z.O. Unerbayeva, K.I. Shalabayev, S.K. Imankulova, J.B. Childibayev, S.V. Sumatokhin, Eurasia Journal of Mathematics, Science and Technology Education, 13(11), 7399 (2017)

2. J. Cooke, Y. Araya, K.L. Bacon, J.M. Bagniewska, L.C. Batty, et al., Oikos, 130(1), 15 (2021)

3. Decree of the President of the Russian Federation "On national goals and strategic objectives of development of the Russian Federation for the period up to 2024" No. 204 of May 7 (2018)

4. S. Sumatokhin, O. Petrova, D. Serovayskaya, F. Chistiakov, Theory and practice of project management in education: horizons and risks, 10 (2020)

5. L.N. Sukhorukova, E.I. Sukhorukova, Psychological Science and Education, 25(3), 5 (2020)

6. S.V. Sumatokhin, Biology at school, 1, 15 (2019)

7. Biology, All-Russian Olympiads, 5 Ring Series, ed. by V.V. Pasechnik, 1, 191 (2008)

8. N.V. Altynikova, A.A. Muzayev, Psychological Science and Education, 24(1), 31 (2019)

9. E.N. Demyankov, A.N. Demyankov, S.V. Sumatokhin, General Biology problem book. Grades 9-11, 272 (2018)

10. M.Y. Demidova, G.S. Demidova, Scientific knowledge of Russian students, http://nmspataru.com/

11. PISA 2015 released filed trial cognitive items, http://www.oecd.org/

12. K. Rabea, H. Sören, W. Nathalie, S. Daniel, B. Christoph, Swiss Medical Weekly, 150(51), w20389 (2020) 